\title{
ELECTRICAL RESISTIVITY IMAGING OF CAVE DIVAŠKA JAMA, SLOVENIA
}

\author{
Mihevc AndreJ' ${ }^{1}$ AND STEPIŠNIK URoŠ²
}

\begin{abstract}
Electrical resistivity imaging is a widely used tool in geophysical surveys for investigation of various subsurface structures. To assess its applicability for subsurface karst, electrical resistivity imaging was conducted in the southeastern part of the karst plateau above Divaška jama and its sediment-filled denuded continuation on the surface. Cave passages that are not filled with sediment were not detected with electrical resistivity imaging, because the electrical resistivity difference between voids and highly resistive carbonate bedrock is small. On the other hand, denuded caves and cave sections that are filled with loamy material can be clearly distinguished from less resistive carbonate bedrock.
\end{abstract}

\section{INTRODUCTION}

The study area is situated in a southeastern part of the Kras plateau called the Divača karst and on the northwestern side of the Divača karst above the caves Divaška jama and Trhlovca and their denuded continuation towards the east. This manuscript discusses the application of electrical resistivity imaging on the surface above known passages in Divaška jama, its presumed subsurface continuation, and its denuded continuation on the rim and slope of collapse doline Gorenjski Radvanj. The main purpose of the paper is to test the applicability of electrical resistivity imaging to the investigation of subsurface structures where there are small resistivity differences.

The Kras is a limestone plateau situated above the Trieste Bay in the northern Adriatic Sea. Stretching in the Dinaric (northwest-southeast) direction, it is $40 \mathrm{~km}$ long, $14 \mathrm{~km}$ wide, and covers about $440 \mathrm{~km}^{2}$. It is morphologically quite distinct from the surrounding regions. Lower flysch regions and the Adriatic Sea bound it on the southwest and the northeast, and to the northwest it is surrounded by the fluvial sediments of the River Soča (Isonzo) plain. Towards the southeast, the border of the Kras is well-defined by the non-carbonate flysch Brkini Hills and the River Reka valley.

The Divača karst is situated in the southeastern part of the Kras plateau between the hinterland of the River Reka ponor and the town of Divača (Fig. 1). The bedrock in the area comprises thickly-bedded Cretaceous limestone, dipping approximately 20 degrees towards the south, and is bounded to the south and north by Paleogene thin-bedded limestone. On the edge of the area, the River Reka sinks into Škocjanske jame at the elevation of $317 \mathrm{~m}$ a.s.l. The terminal sump of this $5800 \mathrm{~m}$ long cave is at $190 \mathrm{~m}$ a.s.l. Beyond about $900 \mathrm{~m}$ of unexplored passages, the underground river flows through $12,750 \mathrm{~m}$ long Kačna jama. The surface of the Divača karst, at approximately $430 \mathrm{~m}$, is largely flat, with numerous solution dolines, collapse dolines, and denuded caves. Solution dolines are 50 to $100 \mathrm{~m}$ in diameter and are about $10 \mathrm{~m}$ deep. Their density can be higher than two hundred dolines per $\mathrm{km}^{2}$. The volumes vary between some thousands to several tens of thousands of cubic meters (Mihevc, 1997). On the surface, there are also twenty-seven large collapse dolines with a total volume of more than $41 \times 10^{6} \mathrm{~m}^{3}$. Their mean depth is about $45 \mathrm{~m}$, and their mean diameter is $135 \mathrm{~m}$. On the planated surface, it is possible to recognize several denuded caves that are mostly unroofed sections of horizontal or sub-horizontal epiphreatic cave passages. The largest section is about $30 \mathrm{~m}$ wide and can be recognized over a distance of about $600 \mathrm{~m}$ (Mihevc, 1997).

The study area (Fig. 2) is situated on the edge of a doline in the northwest part of the Divača karst. The surface is mostly flat at an elevation of about $460 \mathrm{~m}$, and is interrupted by several dolines with diameters up to $100 \mathrm{~m}$ and about $15 \mathrm{~m}$ deep. The eastern part of the surface gradually dips into the elongated depression of a denuded cave that in its eastern part continues into the Divaški Radvanj collapse doline. Two large caves are known in this area. The biggest is Divaška jama, which runs approximately southwest-northeast at an elevation between 350 and $410 \mathrm{~m}$. The other large cave, Trhlovca, is located southwest of Divaška jama.

Divaška jama is developed in bedded limestone of Senonian age (Jurkovšek et al., 1996). Limestone beds in the cave dip toward the southwest in the northeastern part of the cave and toward the south in the southwestern part (Gospodarič, 1985). The cave is a roughly $700 \mathrm{~m}$ long relict of an originally larger cave system of epiphreatic and partially phreatic origin. The main part of the cave consists of a large passage up to $20 \mathrm{~m}$ high and $15 \mathrm{~m}$ wide. The cave is filled with at least $30 \mathrm{~m}$ of lithologically varied sediments and speleothems of different ages. The most extensive sediment in the cave is thick, laminated flood loam. The loam filled up most of the cave, but was later partially eroded away in lower parts by percolating water. Both ends of the cave are choked with allogenic sediments and flowstone. The only known

\footnotetext{
${ }^{1}$ Karst research institute ZRC SAZU, Titov trg 2, SI-6230 Postojna, Slovenia, mihevc@zrc-sazu.si

${ }^{2}$ University of Ljubljana, Department of Geography, Aškerčeva 2, SI-1000 Ljubljana, Slovenia, urosstepisnik@hotmail.com
} 


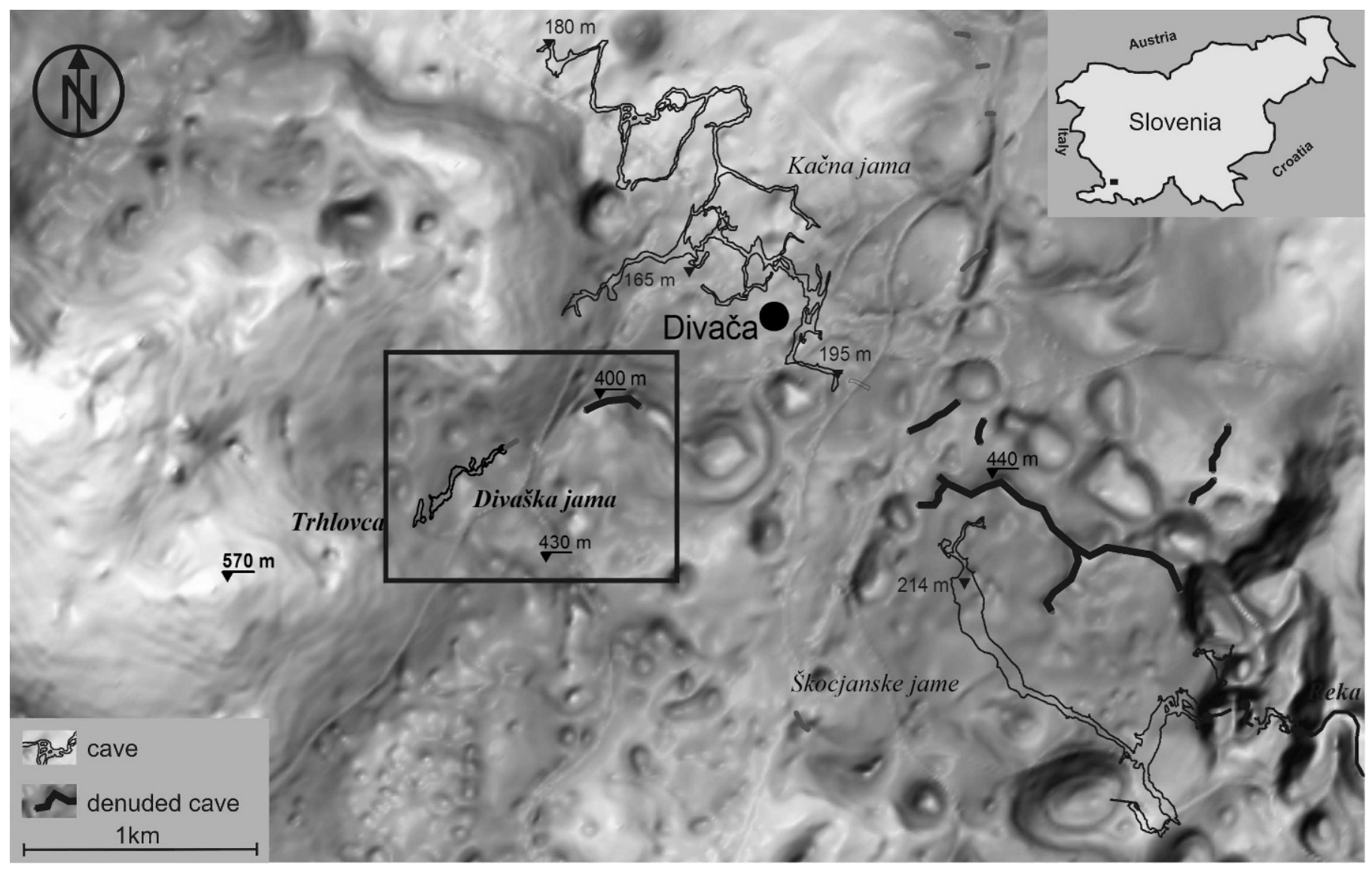

Figure 1. Location of the study area.

subsurface continuation of the Divaška jama is Trhlovca, although they are not directly connected. Trhlovca is $142 \mathrm{~m}$ long and $22 \mathrm{~m}$ deep. The entrance to this cave is below vertical walls at the side of a doline. The doline probably represents the unroofed continuation of the cave, as the passage that connects the main passage with the surface is a phreatic channel intercepted by the surface. The southwestern end of Divaška jama is about $40 \mathrm{~m}$ below the end of this doline. Trhlovca is developed in bedded, southerly dipping limestone of the Sežana formation (Jurkovšek et al., 1996). The main part of the cave is a meandering canyon approximately $15 \mathrm{~m}$ high, about $3 \mathrm{~m}$ wide, and $60 \mathrm{~m}$ long running north-south at an elevation of 404 to $419 \mathrm{~m}$. Scallops and undulating notches are developed on walls, indicating evolution in phreatic and partially in paragenetic conditions. This passage was completely filled with clastic fluvial sediments. The cave became accessible after the sediments were washed out (Zupan Hajna et al., 2008).

In the east of the study area are two collapse dolines, Divaški Radvanj and Gorenjski Radvanj, which is the actual eastern limit of the study area. The slopes of Gorenjski Radvanj are mostly balanced. Lower parts of the slopes are covered with loamy material. On the western slopes there are two erosion gullies filled with sediment consisting of clay, silt and sand, and flowstone.

\section{Methods}

Although electrical resistivity imaging has been successfully utilized for characterizing the subsurface for many years, it has certain limitations. The method is labor intensive, interpretation of the data is time consuming, and the results are based on subjective interpretation (Roman, 1952; Zhou et al., 2002). The development of computer controlled multi-electrode systems and resistivity modeling software have allowed more cost-effective resistivity surveys and better interpretation of the subsurface (Locke and Barker, 1996). These surveys are usually referred to as electrical resistivity imaging (ERI) or electrical resistivity tomography (ERT) (Zhou et al., 2002). These methods allow data to be collected and processed quickly, so that ERI surveys become a valuable tool in subsurface investigations (Zhou et al., 2000).

ERI surveys are typically conducted to determine the resistivity of subsurface features and can be used to determine the location of various geologic and soil strata, bedrock fractures, faults, and voids. Fundamental to all resistivity methods is the concept that current is injected into the ground, and the voltages induced by this current can be measured. These potentials or differences of potential, ratios of potential differences, or some other parameter that is 


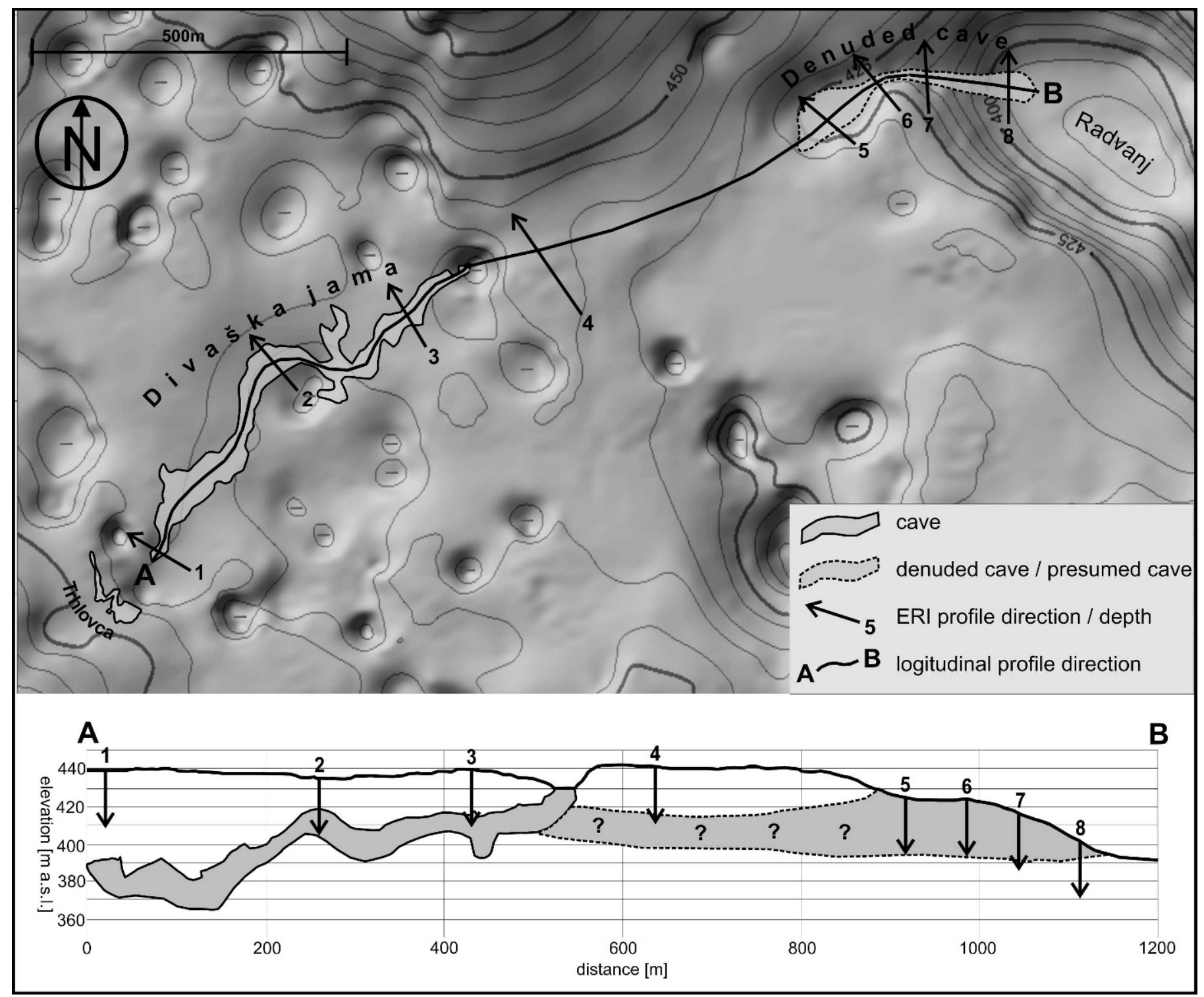

Figure 2. Top: Detailed map of the study area showing the electrical resistivity imaging lines over the cave (1-3), its presumed filled continuation (4), and the unroofed cave at the sinkhole (5-8). Bottom: Profile sketch along the curve A-B in the top part, with depths of the electrical resistivity imaging profiles that were calculated.

directly related to these variables are the most commonly measured effect of the injected current. The principal differences among various methods of electrical resistivity lie in the number and spacing of the current and potential electrodes, the variable calculated, and the manner of presenting the results (Zhou et al., 2000).

Generally, carbonate rock has a significantly higher resistivity than loamy material, because of its considerably smaller primary porosity and fewer interconnected pore spaces. Its resistivity value is about $1000 \mathrm{ohm}-\mathrm{m}$ (Telford et al., 1990). Loamy materials can hold more moisture and have higher concentrations of ions to conduct electricity; therefore, their resistivity values are below $250 \mathrm{ohm}-\mathrm{m}$ (Telford et al., 1990). The high contrast in resistivity values between carbonate rock and loamy material favors the use of electrical resistivity to determine the boundary between bedrock and overburden or loamy sediment (Zhou et al., 2000).

A frequently occurring problem with electrical resistivity imaging is deciding which electrode configuration will respond best to the material changes in karst features. Each type of array has distinctive advantages and disadvantages in terms of sensitivity to material variations, depth from which information may be obtained, and signal strength. The most common arrays are the dipole-dipole array, the Wenner array, and the Schlumberger array. The dipoledipole array gives good horizontal resolution, while the Wenner and Schlumberger arrays are more intended for

Journal of Cave and Karst Studies, December 2012 •237 

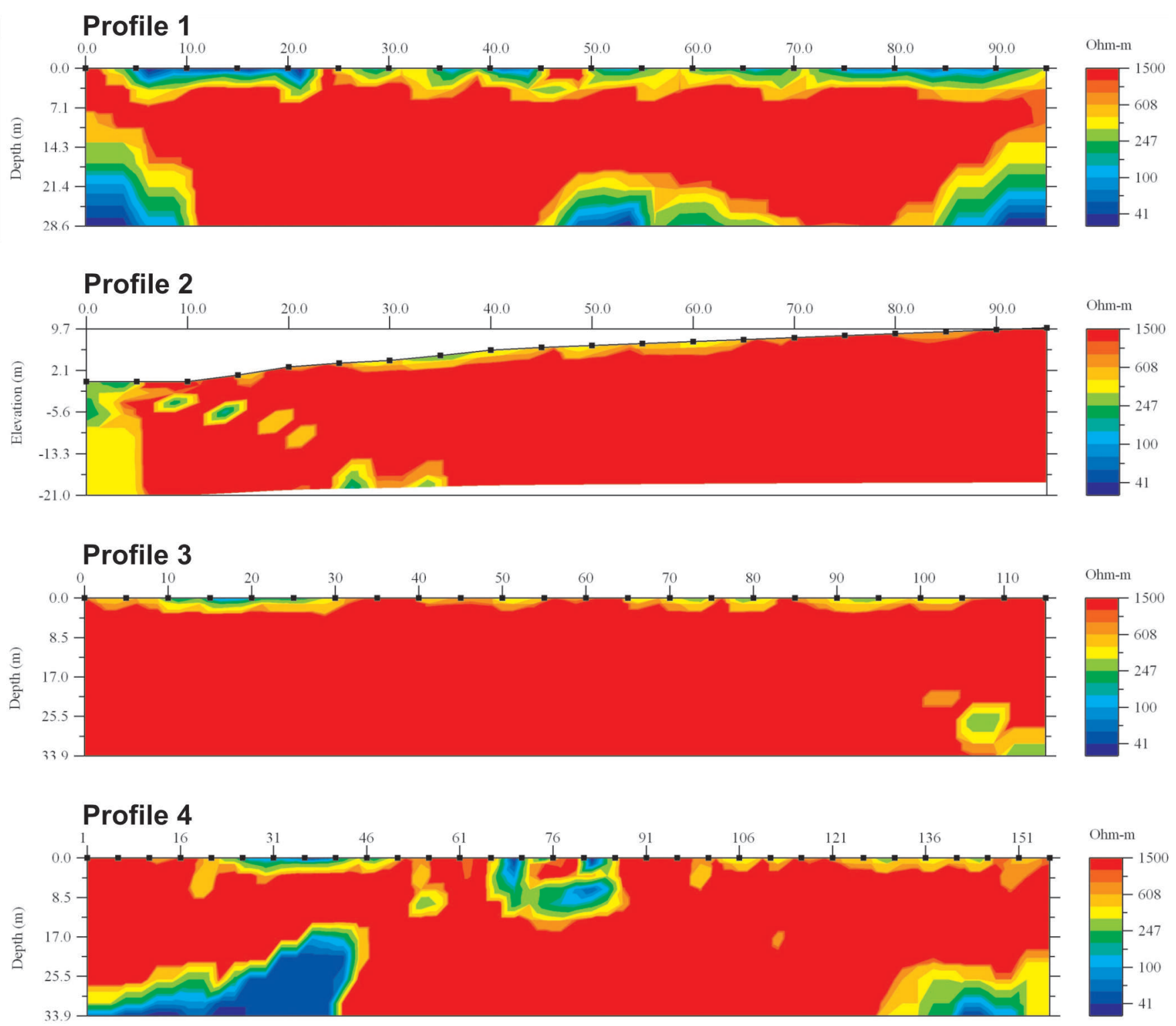

Figure 3. ERI profiles 1-4, scale 0 to $1500 \mathrm{ohm}-\mathrm{m}$.

vertical resolution. In the application to karst surveys, the dipole-dipole array has provided highest precision of ground changes sensitivity and has the greatest sensitivity to vertical resistivity boundaries (Zhou et al., 2002).

Electrical resistivity data were collected along eight different lines above Divaška jama, its presumed continuation, and the denuded section on the slope of the collapse doline (Fig. 2). The SuperSting R1/IP earth resistivity meter developed by Advanced Geosciences, Inc. was used for data collection. The survey was conducted with a dipole-dipole array with $5 \mathrm{~m}$ electrode spacing. In most cases, twenty electrodes were used simultaneously, with alternation of two current and two potential electrodes. For longer profiles, a roll-along survey was used. The data were processed to generate two-dimensional resistivity models using Earthimager 2D resistivity inversion software developed by Advanced Geosciences, Inc. This combination of equipment and software have been shown to be appropriate for providing a robust visualization of the epikarst structure and the subsurface structure of collapse dolines (Stepišnik and Mihevc, 2008; Stepišnik, 2008). The root-mean-square error quantifies the difference between the measured resistivity values and those calculated from the true resistivity model. A small RMS value indicates small differences. The minimum RMS error in the survey was $2.59 \%$, and the maximum error was $8.2 \%$.

Previous applications of this method in various karst features in the Slovenian karst revealed that the resistivity value for carbonate rock exceeds $1000 \mathrm{ohm}-\mathrm{m}$. For soil and weathered bedrock, the resistivity values are between approximately 200 and $1000 \mathrm{ohm}-\mathrm{m}$. Loamy material has resistivity values lower than $150 \mathrm{ohm}-\mathrm{m}$ (Stepišnik, 2007; 

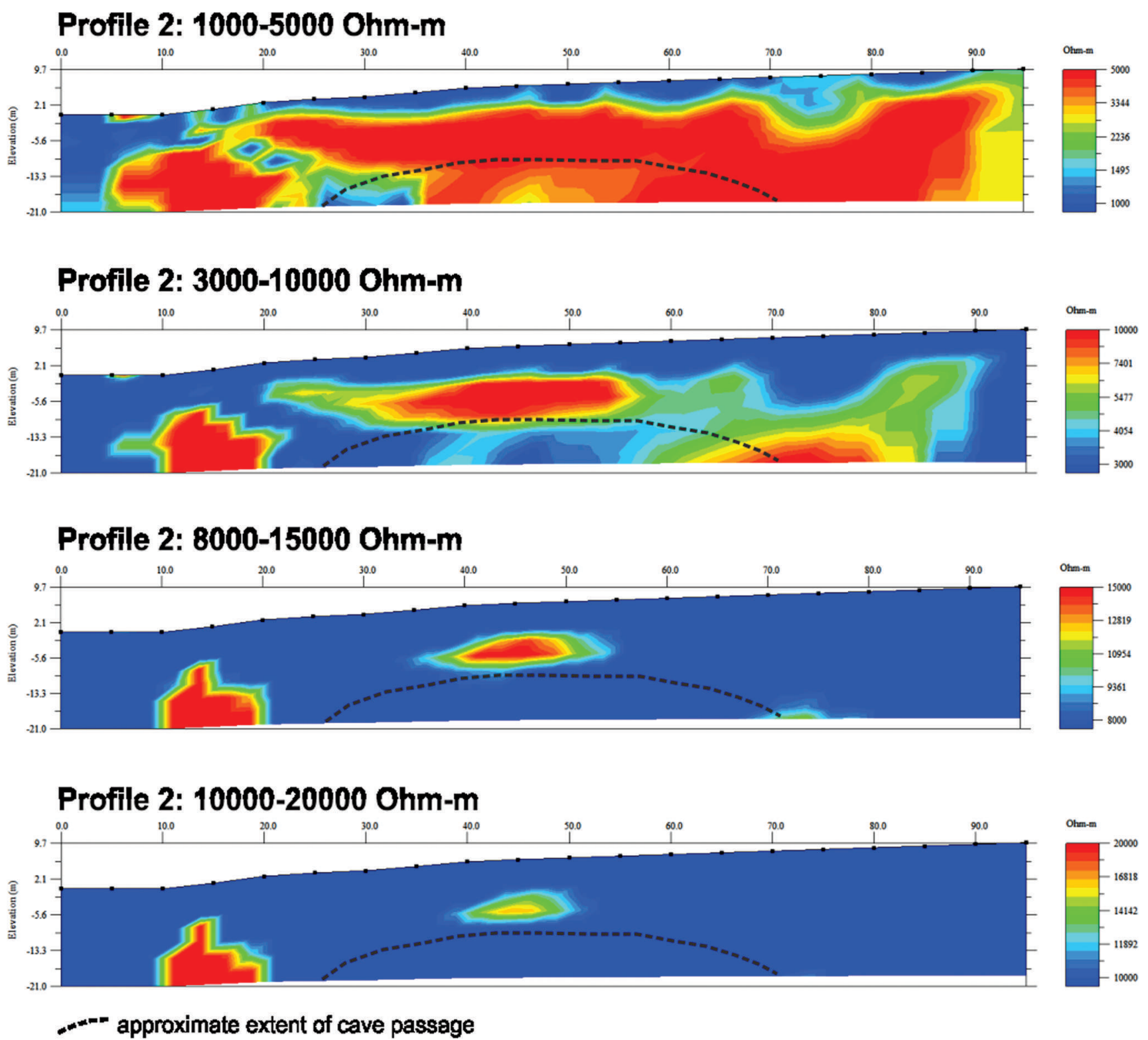

Figure 4. ERI profile 2 computed with additional higher scales of resistivity values.

Stepišnik and Mihevc, 2008; Stepišnik, 2008). However, threshold resistivity values that would discriminate between voids and carbonate bedrock have not yet been determined. Since voids should have infinite resistivity, the analysis was repeated at different ranges of resistivity to check if subsurface openings can be detected.

The ERI profiles across Divaška jama (profiles 1, 2 and 3) exhibit relatively uniform subsurface structure, which is a result of the high electrical resistivity of limestone bedrock, as well as cave voids (Fig. 3). Line 1 was situated on the surface above the southeastern end of the Divaška jama, oriented $290^{\circ}$. Even though the surface is gently inclined towards the north, the inclination is uniform, and so for the purpose of the analysis, the topography of the profile is presented as flat (Fig. 3). In this profile, bedrock with resistivity value more than $1000 \mathrm{ohm}-\mathrm{m}$ is covered by thin layers of less resistive soil, mechanically weathered rock, or loamy material with resistivity about $500 \mathrm{ohm}-\mathrm{m}$. In the central part of the profile, at the depth of about $25 \mathrm{~m}$ there is a clearly distinguished area with electrical resistivity lower than 500 ohm-m, which might be a high-level extension of Divaška jama towards Trhlovca that is completely choked with loamy sediment. Known passages of Divaška jama are positioned about $50 \mathrm{~m}$ below the surface and were not detected in the ERI profile, as the maximum depth in this profile was $28 \mathrm{~m}$.

Line 2 was situated above the central part of Divaška jama that lies approximately $15 \mathrm{~m}$ below the surface. The surface is on the northwestern slope of a doline in the direction of $300^{\circ}$. In this profile, bedrock with resistivity value more than 


\section{Profile 5}
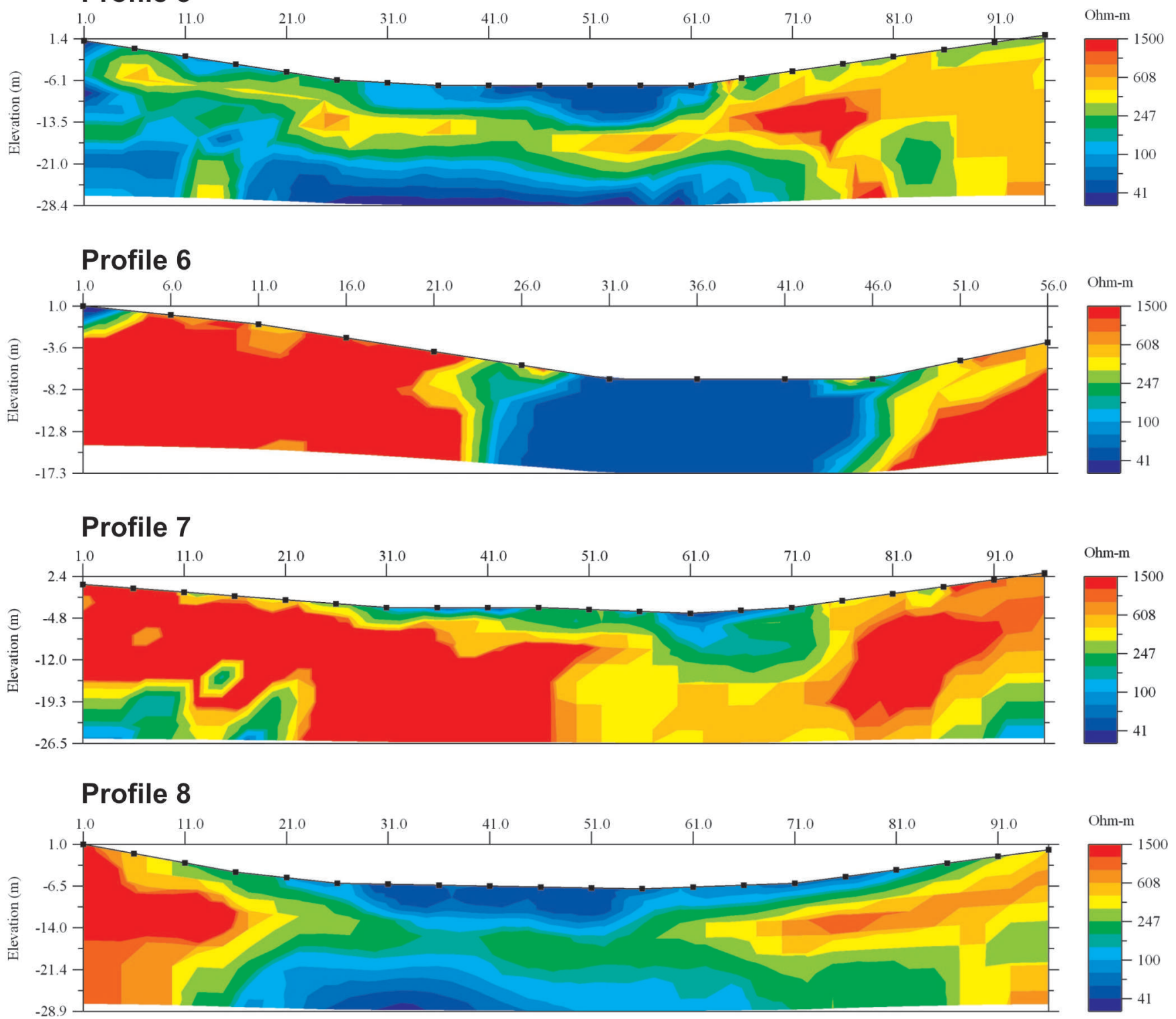

Figure 5. ERI profiles 5-8, scale 0 to $1500 \mathrm{ohm}-\mathrm{m}$.

$1000 \mathrm{ohm}-\mathrm{m}$ is covered by thin layers of less resistive soil, mechanically weathered rock, or loamy material with resistivity about $500 \mathrm{ohm}-\mathrm{m}$. In the central part of the profile, at the depth of about $15 \mathrm{~m}$, a cave passage in Divaška jama is present. It should be seen on the profile, as resistivity values should be extremely high. However, resistivity values of the whole section of the profile appear like those of the surrounding bedrock. Different ranges of resistivity values were used in an attempt to find a resistivity threshold between the cave passage and the surrounding bedrock (Fig. 4). None of the applied ranges, differing by an order of magnitude, allowed us detect the actual cave chamber. At higher resistivity values, some anomalies were detected that might be tensional fractures above the cave (15000 and $20000 \mathrm{ohm}-$ $\mathrm{m})$, but they are not at the depth of the cave.
Line 3 was situated near the northeastern end of Divaška jama, which here lies approximately $22 \mathrm{~m}$ below the surface. The line ran across a flat karst surface covered with grikes, in the direction of $305^{\circ}$. In this profile, bedrock with resistivity value more than $1000 \mathrm{ohm}-\mathrm{m}$ is covered by thin layers of less resistive soil, mechanically weathered rock, or loamy material with resistivity about $500 \mathrm{ohm}-\mathrm{m}$. Passages in Divaška jama lie in the central part of the profile, but they were not detected by use of ERI because they have the same apparent resistivity values as the surrounding bedrock.

Profile 4 is situated on a flat karst surface beyond the northeastern end of Divaška jama, over its presumed subsurface continuation toward denuded cave next to the Gorenjski Radvanj collapse doline (Fig. 4). In this area, no 
accessible cave is known. Direction of the profile is $300^{\circ}$. In this profile, too, bedrock with resistivity value more than $1000 \mathrm{ohm}-\mathrm{m}$ is partially covered by thin layers of less resistive soil, mechanically weathered rock, or loamy material with resistivity about $500 \mathrm{ohm}-\mathrm{m}$. In the central part of the profile, from the surface to the depth of about $10 \mathrm{~m}$, there is evidence of a small subsurface structure with resistivity values less than $500 \mathrm{ohm}-\mathrm{m}$. Most likely the structure is part of an epikarst void filled with loamy material or soil. Here too, distinct grikes are present on the surface. In the southeastern section of the profile at depths greater than $17 \mathrm{~m}$, a subsurface structure with a diameter of about $30 \mathrm{~m}$ is evident. With resistivity values less than $500 \mathrm{ohm}-\mathrm{m}$, the structure is apparently a cave passage completely filled with loamy material. This presumably is a continuation of Divaška jama.

Lines 5 through 8 ran across the unroofed cave section completely filled with loamy material and flowstone (Fig. 5). Results of ERI exhibit a clear difference between cave fill and bedrock. Line 5, in the direction of $290^{\circ}$, was placed over the southwestern section of the denuded cave trench. Its profile exhibits some bedrock with resistivity value around $1000 \mathrm{ohm}-\mathrm{m}$ in the southeastern section. It is covered with a thin layer of electrically less resistive soil, mechanically weathered rock, or loamy material with resistivity value about $500 \mathrm{ohm}-\mathrm{m}$. All other parts of the profile exhibit some resistivity values lower than $150 \mathrm{ohm}-$ $\mathrm{m}$ that indicates loamy material and flowstone fill material in a denuded cave. Material with resistivity values around $500 \mathrm{ohm}-\mathrm{m}$ located in the central and northwestern sections of the profile at a depth between 10 and $15 \mathrm{~m}$ is probably weathered bedrock that accumulated there due to slope processes inside the denuded cave.

Line 6 was situated on the denuded cave northeast of line 5 , on the rim of the collapse doline. The line was run at $290^{\circ}$, perpendicular to the direction of the denuded cave. In the resulting profile, bedrock with resistivity value more than $1000 \mathrm{ohm}-\mathrm{m}$ is present on both slopes of the trench. It is partially covered with thin layers of electrically less resistive soil, mechanically weathered rock, or loamy material with resistivity value about $500 \mathrm{ohm}-\mathrm{m}$. The central part of the profile shows over $15 \mathrm{~m}$ of loamy material and flowstone fragments with resistivity values below 150 ohm-m.

Line 7 , run at $350^{\circ}$, was placed on the western slope of the collapsed doline close to the denuded cave. Bedrock, with resistivity values more than $1000 \mathrm{ohm}-\mathrm{m}$, is present along the whole profile. A low-resistivity area (below $150 \mathrm{ohm}-\mathrm{m})$ in the central part of the profile, where the surface is covered with loam and flowstone particles, is up to $10 \mathrm{~m}$ thick.

Line 8 was situated on the floor of the western part of the collapse doline just under the slope where the denuded cave is disintegrating. Both ends of the profile show the presence of bedrock, with resistivity values higher than $1000 \mathrm{ohm}-\mathrm{m}$, on the slopes of the collapse doline. In the upper part of central section of the profile, material with resistivity values lower than $150 \mathrm{ohm}-\mathrm{m}$ appears up to a depth of $5 \mathrm{~m}$. This is most likely loamy outwash of the denuded cave fill from the slope. Below the outwash, at depths between 5 to $15 \mathrm{~m}$, the profile shows resistivity values from 150 to $500 \mathrm{ohm}-\mathrm{m}$ that most likely represent weathered bedrock accumulated as scree at the foot of the slope. Below, there is again the material that exhibits resistivity values lower than $150 \mathrm{ohm}-\mathrm{m}$, suggesting loamy fill in the doline (Stepišnik, 2008).

\section{Conclusions}

Electrical resistivity imaging data were collected for eight lines over caves Divaška jama and Trhlovca and across their denuded continuation on the slope of the collapse doline Gorenjski Radvanj.

The ERI profiles across Divaška jama (profiles 1, 2 and 3) exhibit relatively uniform subsurface structure that is a result of the high electrical resistivity of limestone bedrock and cave voids. Although the cave passages are relatively close to the surface, they were not detected with the application of ERI, even at the highest resistivity values that should show the difference between bedrock and void.

Profile 4, across the presumed underground continuation of Divaška jama in the direction of the unroofed cave shows some differences in subsurface electrical resistivity that may indicate the existence of cave conduits completely filled with less resistive loamy material. The unroofed section of the cave is completely filled with loamy material and flowstone. ERI profiles 4, 5, 6, and 7 exhibit a clear difference between allogenic cave fill and bedrock. In the upper section above the slopes of the collapse doline, where the denuded cave is up to $20 \mathrm{~m}$ wide, the loamy fill is $15 \mathrm{~m}$ thick. On the slopes, the thickness of loamy fill diminishes, probably because it has been washed into the doline. The ERI profile in the lower section of the slope exhibits up to $25 \mathrm{~m}$ of loamy material fill.

Application of the ERI method has proved appropriate for detailed investigation of subsurface structures with large differences in electrical resistivity. Parts of denuded caves and cave passages that are filled with loamy material can be clearly distinguished from less resistive carbonate bedrock. In the measured ERI profiles, resistivity values of soil- and sediment-filled features are lower than $150 \mathrm{ohm}-\mathrm{m}$ and weathered bedrock is around $500 \mathrm{ohm}-\mathrm{m}$, while bedrock exhibits values higher than $1000 \mathrm{ohm}-\mathrm{m}$.

On the other hand, underground parts of the caves with huge chambers were not detected in this survey by ERI method, as resistivity differences between voids and the highly resistive carbonate bedrock are insignificant. In calculated profiles with high maximum resistivity (Fig. 4), limestone bedrock exhibits resistivity values approximately between 5000 and 10000 ohm-m. Previous applications of ERI over cave passages gave resistivity values of limestone bedrock up to $5000 \mathrm{ohm}-\mathrm{m}$, while voids have higher values 
(e.g., Barbadello et al., 2002; Brown et al., 2011). In this case, the problem of not detecting the voids seems to be a consequence of the very high electrical resistivity of this type of limestone.

\section{REFERENCES}

Barbadello, L., Bratus, A., Yabar, D.N., Paganini, P., and Palmieri, F., 2002, Integrated geophysical methods to define hypogenous karstic features: Atti del Museo Civico di Storia Naturale di Trieste, v. 40, p. 15-21.

Brown, W.A., Stafford, K.W., Shaw-Faulkner, M., and Grubbs, A., 2011, A comperative integrated geophysical study of Horseshoe Chimney Cave, Colorado Bend State Park, Texas: International Journal of Speleology, v. 40, no. 1, p. 9-16.

Gospodarič, R., 1985, O speleogenezi Divaške jame in Trhlovce: Acta Carsologica, v. 13 , p. 5-34.

Jurkovšek, B., Toman, M., Ogorelec, B., Šribar, L., Drobne, K., Poljak, M., and Šribar, L., 1996, Formacijska geološka karta južnega dela Tržaško - komenske planate 1:50.000: kredne in paleogenske karbonatne kamnine, Ljubljana, Inštitut za geologijo, geotehniko in geofiziko, $143 \mathrm{p}$.

Mihevc, A., 1997, Dolines, their morphology and origin, case study: dolines from the Kras, west Slovenia (the Skocjan karst), in James, J., and Forti, P., eds., Fourth International Conference on Geomor- phology, Karst Geomorphology (Geografia Fisica e Dinamica Quaternaria, Supplement 3, part 3), p. 69-74.

Roman, I., 1952, Resistivity reconnaissance, in Symposium on Surface and Subsurface Reconnaissance, Philadelphia, American Society for Testing Materials, Special Technical Publication 122, p. 171-226.

Stepišnik, U., 2007, Loamy sediment fills in collapse dolines near the Ljubljanica River springs, Dinaric Karst, Slovenia: Cave and Karst Science, v. 33, p. 105-110.

Stepišnik, U., 2008, The application of electrical resistivity imaging in collapse doline floors: Divača karst, Slovenia: Studia Geomorphologica Carpatho-Balcanica, v. 42, p. 41-56.

Stepišnik, U., and Mihevc, A., 2008, Investigation of structure of various surface karst formations in limestone and dolomite bedrock with application of the electrical resistivity imaging: Acta Carsologica, v. 37 , no. 1 , p. $133-140$.

Telford, W.M., Geldart, L.P., and Sheriff, R.E., 1990, Applied Geophysics (2. edition): New York, Cambridge University Press, 790 p.

Zhou, W., Beck, B.F., and Adams, A.L., 2002, Effective electrode array in mapping karst hazards in electrical resistivity tomography: Environmental Geology, v. 42, p. 922-928. doi:10.1007/s00254-002-0594-z.

Zhou, W., Beck, B.F., and Stephenson, J.B., 2000, Reliability of dipoledipole electrical resistivity tomography for defining depth to bedrock in covered karst terrains: Environmental Geology, v. 39, p. 760-766. doi: $10.1007 / \mathrm{s} 002540050491$.

Zupan Hajna, N., Mihevc, A., Pruner, P., and Bosák, P., 2008, Paleomagnetism and magnetostratigraphy of karst sediments in Slovenia, Ljubljana, Založba ZRC, Carsologica Series, 266 p. 